Atmos. Chem. Phys., 13, 5337-5350, 2013

www.atmos-chem-phys.net/13/5337/2013/

doi:10.5194/acp-13-5337-2013

(C) Author(s) 2013. CC Attribution 3.0 License.

\title{
Particle and gaseous emissions from individual diesel and CNG buses
}

\author{
Å. M. Hallquist ${ }^{1}$, M. Jerksjö ${ }^{1}$, H. Fallgren ${ }^{1}$, J. Westerlund ${ }^{2}$, and Å. Sjödin ${ }^{1}$ \\ ${ }^{1}$ IVL Swedish Environmental Research Institute, Gothenburg, Sweden \\ ${ }^{2}$ University of Gothenburg, Department of Chemistry and Molecular Biology, Atmospheric Science, Gothenburg, Sweden \\ Correspondence to: Å. M. Hallquist (asa.hallquist@ivl.se)
}

Received: 14 July 2012 - Published in Atmos. Chem. Phys. Discuss.: 22 October 2012

Revised: 17 March 2013 - Accepted: 20 March 2013 - Published: 27 May 2013

\begin{abstract}
In this study size-resolved particle and gaseous emissions from 28 individual diesel-fuelled and 7 compressed natural gas (CNG)-fuelled buses, selected from an in-use bus fleet, were characterised for real-world dilution scenarios. The method used was based on using $\mathrm{CO}_{2}$ as a tracer of exhaust gas dilution. The particles were sampled by using an extractive sampling method and analysed with high time resolution instrumentation EEPS $(10 \mathrm{~Hz})$ and $\mathrm{CO}_{2}$ with a non-dispersive infrared gas analyser (LI840, LI-COR Inc. $1 \mathrm{~Hz}$ ). The gaseous constituents (CO, HC and NO) were measured by using a remote sensing device (AccuScan RSD 3000, Environmental System Products Inc.). Nitrogen oxides, $\mathrm{NO}_{\mathrm{x}}$, were estimated from $\mathrm{NO}$ by using default $\mathrm{NO}_{2} / \mathrm{NO}_{\mathrm{x}}$ ratios from the road vehicle emission model HBEFA3.1. The buses studied were dieselfuelled Euro III-V and CNG-fuelled Enhanced Environmentally Friendly Vehicles (EEVs) with different after-treatment, including selective catalytic reduction (SCR), exhaust gas recirculation (EGR) and with and without diesel particulate filter (DPF). The primary driving mode applied in this study was accelerating mode. However, regarding the particle emissions also a constant speed mode was analysed. The investigated CNG buses emitted on average a higher number of particles but less mass compared to the diesel-fuelled buses. Emission factors for number of particles $\left(\mathrm{EF}_{\mathrm{PN}}\right)$ were $\mathrm{EF}_{\mathrm{PN}, \mathrm{DPF}}=4.4 \pm 3.5 \times 10^{14}, \mathrm{EF}_{\mathrm{PN}, \text { no } \mathrm{DPF}}=2.1 \pm 1.0 \times 10^{15}$ and $\mathrm{EF}_{\mathrm{PN}, \mathrm{CNG}}=7.8 \pm 5.7 \times 10^{15} \mathrm{~kg} \mathrm{fuel}^{-1}$. In the accelerating mode, size-resolved emission factors (EFs) showed unimodal number size distributions with peak diameters of 70$90 \mathrm{~nm}$ and $10 \mathrm{~nm}$ for diesel and CNG buses, respectively. For the constant speed mode, bimodal average number size distributions were obtained for the diesel buses with peak modes of $\sim 10 \mathrm{~nm}$ and $\sim 60 \mathrm{~nm}$.
\end{abstract}

Emission factors for $\mathrm{NO}_{\mathrm{x}}$ expressed as $\mathrm{NO}_{2}$ equivalents for the diesel buses were on average $27 \pm 7 \mathrm{~g}(\mathrm{~kg} \text { fuel })^{-1}$ and for the CNG buses $41 \pm 26 \mathrm{~g}$ (kg fuel) ${ }^{-1}$. An antirelationship between $\mathrm{EF}_{\mathrm{NO}_{\mathrm{x}}}$ and $\mathrm{EF}_{\mathrm{PM}}$ was observed especially for buses with no DPF, and there was a positive relationship between $\mathrm{EF}_{\mathrm{PM}}$ and $\mathrm{EF}_{\mathrm{CO}}$.

\section{Introduction}

It is acknowledged that combustion processes, especially traffic-related emissions, contribute significantly to total particulate air and gaseous pollutants in urban environments. Many epidemiological studies have shown that particles have adverse health effects (Pope and Dockery, 2006). Particles also have an effect on climate either directly via scattering and absorption of radiation or indirectly via its influence on the formation of clouds.

When measuring particle emissions, mass basis is often used. This implies that such data are dominated by large particles. Numerically vehicle exhaust is dominated by ultrafine particles (UFPs), i.e. particles with a diameter $<100 \mathrm{~nm}$ (Janhall et al., 2004; Harrison et al., 1999; Kumar et al., 2010). Therefore an alternative way of presenting particle emissions is needed - i.e. looking at the number of particles emitted - to enable accounting for the small particles that on a mass basis are negligible. Further, health risks are probably dominated by the UFPs (Donaldson et al., 1998; Delfino et al., 2005; Valavanidis et al., 2008). Thus, there is an obvious need to ascertain the emission of particles from traffic regarding number and size in order to establish effective air quality management strategies. 
Particles measured in close vicinity of the emission source are primary, i.e. emitted as particles from the tailpipe, or secondary, i.e. formed during the expansion and cooling of the hot exhaust gases. The former are often in the form of agglomerates of solid phase material, whereas the latter are more volatile (Morawska et al., 2008). Additionally, traffic contributes to the formation of secondary organic aerosols (SOAs); however, the magnitude of this contribution is very uncertain (Robinson et al., 2007). This is a chemically induced particle formation (time scales of hours to days) which is very important on a regional and global scale (Hallquist et al., 2009).

The particle emissions from any combustion source can be derived from the emission ratio of the particle concentration to a co-emitted trace gas, such as $\mathrm{CO}_{2}$ or $\mathrm{NO}_{\mathrm{x}}$ (Janhall and Hallquist, 2005). Knowing the emission factor for the chosen trace gas $\left(\mathrm{EF}_{\text {gas }}\right)$, an emission factor for particle number $\left(\mathrm{EF}_{\mathrm{PN}}\right)$ or mass $\left(\mathrm{EF}_{\mathrm{PM}}\right)$ can be estimated (Hak et al., 2009).

$\mathrm{EF}_{\mathrm{PN} / \mathrm{PM}}=\frac{\Delta \text { part }}{\Delta \text { gas }} \times \mathrm{EF}_{\mathrm{gas}}$,

where $\Delta$ part and $\Delta$ gas are measured changes in the concentration of particle number/mass and trace gas, respectively. Alternative ways of measuring particle emissions from vehicles are at the kerbside, often giving values for the average fleet, or by chassis dynamometer, measuring vehicles individually (e.g. Janhall et al., 2004; Wang et al., 1997; BanWeiss et al., 2010). However, in the latter case it is difficult, if not impossible, to accurately mimic the real-world dilution. Additionally, there are chase-car experiments where the test vehicle is followed by an instrumented vehicle (e.g. Pirjola et al., 2004; Vogt et al., 2003). A challenge with this method is to avoid being influenced by other vehicles as well as keeping the distance between the target vehicle and the chasing vehicle constant. Knowledge about emissions from the on-road fleet under real-world conditions is crucial. In a recent study, $\mathrm{EF}_{\mathrm{PN}}$ was measured at the kerbside for individual vehicles for real-world dilution (Hak et al., 2009).

Along with particles, nitrogen oxides, $\mathrm{NO}_{\mathrm{x}}$, are depicted as being the most problematic pollutant from internal combustion engines (Lopez et al., 2009). In order to meet the lower $\mathrm{NO}_{\mathrm{x}}$ and particle emission levels introduced for heavy duty vehicles (HDVs), exhaust gas after-treatment has become necessary. To reduce particle emissions from HDVs, diesel particulate filters (DPFs) are widely used. An example of after-treatment technology to reduce $\mathrm{NO}_{\mathrm{x}}$ is selective catalytic reduction (SCR), which can be found in power plants, ships and lately also in HDVs. The most common method is SCR with urea injection due to urea's low toxicity and ease in handling, but direct injection of $\mathrm{NH}_{3}$ can also be used. In the SCR system the urea/water mixture (e.g. AdBlue ${ }^{\circledR}$ ) is first added to the exhaust gas which becomes hydrolysed to $\mathrm{NH}_{3}$ and $\mathrm{CO}_{2}$. In the SCR catalyst section $\mathrm{NH}_{3}$ reacts with $\mathrm{NO}_{\mathrm{x}}$ to form $\mathrm{N}_{2}$ and $\mathrm{H}_{2} \mathrm{O}$. Another common approach to reduce $\mathrm{NO}_{\mathrm{x}}$ emissions is exhaust gas recirculation (EGR). By keep- ing a low combustion temperature and low oxygen content the formation of $\mathrm{NO}_{\mathrm{x}}$ is unfavourable; this can be achieved by recirculating a small fraction of the exhaust gas back to the cylinders.

Emissions from new HDVs in Europe are regulated by Euro standards. Currently in force since 2008 is the Euro V standard, and the Euro VI standard will be implemented in 2013. Enhanced Environmentally Friendly Vehicle, EEV, is a voluntary environmental standard which requires lower emission levels than Euro V. It was introduced together with the Euro IV and Euro V emission standards as an incentive to develop vehicles with even lower emission levels than required by regulations, and is mostly applicable to CNG heavy duty vehicles.

In order to meet the challenges with increased transportation, decreased oil resources and enhanced greenhouse gas emissions, the European Union has decided on a $10 \%$ substitution of traditional fuels in the road transport sector (petrol and conventional diesel) by alternative fuels by the year 2020. However, the emissions from vehicles using alternative fuels have to be thoroughly studied to avoid introduction of air pollutants that can have severe health/environmental effects or other so far unknown effects or, alternatively, to establish the advantages from using these fuels.

In the literature there are some studies that have compared the particle emissions from diesel-fuelled and CNG-fuelled buses (Jayaratne et al., 2008, 2009; Wang et al., 1997; Ullman et al., 2003; Lanni et al., 2003; Norman et al., 2002; Clark et al., 1999). This study takes these investigations further by determining both gaseous $\left(\mathrm{NO}_{\mathrm{x}}, \mathrm{CO}\right.$ and $\left.\mathrm{HC}\right)$ and size-resolved particle emission factors for $\mathrm{CNG}$ and diesel buses belonging to different Euro classes with various aftertreatment equipment, i.e. EGR and SCR, for real-world dilution scenarios.

\section{Experimental method}

In this study particle and gaseous emissions from individual vehicles were determined by measuring the concentration change in the diluted exhaust plume compared to the concentrations before the passage and relative to the change in $\mathrm{CO}_{2}$ concentration. By this method it is not necessary to measure absolute concentrations as the relation to $\mathrm{CO}_{2}$ is assumed to be constant during dilution (Jayaratne et al., 2005, 2010; Canagaratna et al., 2004; Shi et al., 2002; Hak et al., 2009). In addition, this method enables deriving size-resolved EFs (Janhall and Hallquist, 2005).

In total 35 different buses were studied, 28 diesel buses and 7 CNG buses. A summary of their technical characteristics including fuel used, Euro class, after-treatment system, year taken into service and kilometres travelled is shown in Table 1.

The measurements were performed at five different locations in connection to the bus depots with limited influence 
Table 1. Technical data of the buses studied.

\begin{tabular}{|c|c|c|c|c|c|}
\hline Bus no & $\begin{array}{l}\text { Euro } \\
\text { class }\end{array}$ & Fuel $^{\mathrm{a}}$ & After-treatment ${ }^{\mathrm{b}}$ & $\begin{array}{l}\text { Year taken } \\
\text { into service }\end{array}$ & $\begin{array}{l}\text { Distance travelled } \\
\qquad\left(10^{3} \mathrm{~km}\right)\end{array}$ \\
\hline 1 & $\mathrm{III}^{\mathrm{c}}$ & Diesel & SCR, DPF & 2004 & 525 \\
\hline 2 & $\mathrm{III}^{\mathrm{c}}$ & Diesel & SCR, DPF & 2004 & 516 \\
\hline 3 & III & Diesel & DPF & 2003 & 454 \\
\hline 4 & III & Diesel & DPF & 2002 & 995 \\
\hline 5 & III & Diesel & DPF & 2002 & 584 \\
\hline 6 & III & Diesel & DPF & 2002 & 523 \\
\hline 7 & III & Diesel & - & 2004 & 232 \\
\hline 8 & III & Diesel & - & 2004 & 285 \\
\hline 9 & IV & Diesel & EGR, DPF & 2006 & 393 \\
\hline 10 & IV & Diesel & EGR, DPF & 2006 & 3.74 \\
\hline 11 & IV & Diesel & EGR & 2008 & 116 \\
\hline 12 & IV & Diesel & EGR & 2006 & 597 \\
\hline 13 & IV & Diesel & EGR & 2010 & 182 \\
\hline 14 & $\mathrm{EEV}^{\mathrm{d}}$ & $\mathrm{CNG}$ & - & 1999 & 598 \\
\hline 15 & EEV & $\mathrm{CNG}$ & - & 2004 & 397 \\
\hline 16 & EEV & $\mathrm{CNG}$ & - & 2004 & 365 \\
\hline 17 & EEV & $\mathrm{CNG}$ & - & 2008 & 157 \\
\hline 18 & EEV & $\mathrm{CNG}$ & - & 2008 & 153 \\
\hline 19 & EEV & $\mathrm{CNG}$ & EGR & 2004 & 450 \\
\hline 20 & EEV & $\mathrm{CNG}$ & EGR & 2004 & 482 \\
\hline 21 & V & Diesel & SCR, DPF & 2009 & 55.8 \\
\hline 22 & V & Diesel & SCR & 2009 & $\mathrm{n} \cdot \mathrm{a}^{\mathrm{e}}$ \\
\hline 23 & V & Diesel & SCR & 2007 & 347 \\
\hline 24 & V & Diesel & SCR & 2007 & 307 \\
\hline 25 & $\mathrm{~V}$ & Diesel & SCR & 2009 & 171 \\
\hline 26 & V & Diesel & SCR & 2007 & 336 \\
\hline 27 & V & Diesel & SCR & 2007 & 351 \\
\hline 28 & $\mathrm{~V}$ & Diesel & SCR & 2007 & 143 \\
\hline 29 & $\mathrm{~V}$ & Diesel & EGR, DPF & 2009 & 123 \\
\hline 30 & $\mathrm{~V}$ & Diesel & SCR & 2007 & 28.6 \\
\hline 31 & V & Diesel & SCR & 2007 & 3924 \\
\hline 32 & $\mathrm{~V}$ & Diesel & SCR & 2007 & 209 \\
\hline 33 & $\mathrm{~V}$ & Diesel & SCR & 2007 & 371 \\
\hline 34 & $\mathrm{~V}$ & Diesel & SCR & 2009 & 104 \\
\hline 35 & V & Diesel & SCR & 2010 & 71.2 \\
\hline
\end{tabular}

from other traffic. Each bus passed the remote sensing and EEPS instrumentation in two driving modes: (1) acceleration from standstill to about $20 \mathrm{~km} \mathrm{~h}^{-1}$, and (2) constant speed of about $20 \mathrm{~km} \mathrm{~h}^{-1}$. Before the buses were measured they were driven a distance, assuring the engines to be fully warmed up. Each bus was tested at least three times, but often more repetitions were performed.

\subsection{Particle sampling}

The sampling of the particle emissions was conducted according to Hak et al. (2009), i.e. an extractive sampling of the passing bus plumes where the sample was continuously drawn through a cord-reinforced flexible conductive tubing. The particles were measured with an EEPS (Engine Exhaust Particle Sizer Spectrometer, Model 3090, TSI Inc.). With this instrument, particle size distributions both regarding mass and number can be obtained in the size range of 5.6-560 nm and with a time resolution of $10 \mathrm{~Hz}$. When determining the mass of particles emitted, spherical particles with unit density were assumed. The $\mathrm{CO}_{2}$ concentration was measured with a non-dispersive infrared gas analyser (LI-840, LI-COR Inc.) with a time resolution of $1 \mathrm{~Hz}$ (Fig. 1).

In order to prevent the influence of the ambient temperature on the measurements for the different measurement 


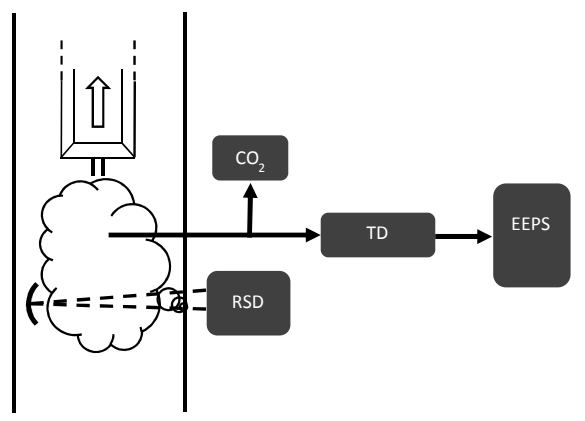

Fig. 1. Schematic of the experimental set-up used. EEPS (Engine Exhaust Particle Sizer Spectrometer, Model 3090, TSI Inc.), RSD (Remote Sensing Device, AccuScan RSD 3000, Environmental System Products Inc.) and TD (thermodenuder; Dekati).

days, the extracted sample flow was heated to $298 \mathrm{~K}$ before the analysis using a thermodenuder (TD; Dekati). Sizedependent aerosol losses within the TD were accounted for (user manual).

\subsection{Gas sampling}

The gaseous constituents NO, $\mathrm{HC}$ and $\mathrm{CO}$ were measured by using a remote sensing device (AccuScan RSD 3000, Environmental System Products Inc.). This equipment was set up with a transmitter and a receiver on one side of the passing lane and a reflector on the other (Fig. 1). The principle of this instrument has been described in detail elsewhere (Burgard et al., 2006) and will only be briefly presented here. This instrumental set-up generates and monitors a co-linear beam of IR and UV light emitted and reflected. Concentrations are determined relative to the concentration of $\mathrm{CO}_{2}$ with a time resolution of $100 \mathrm{~Hz}$. For detecting $\mathrm{CO}, \mathrm{HC}$ and $\mathrm{CO}_{2}$ the absorptions in the IR region at $2150 \mathrm{~cm}^{-1}, 2970 \mathrm{~cm}^{-1}$ and $2350 \mathrm{~cm}^{-1}$, respectively, are used. For NO the absorption in the UV region at $227 \mathrm{~nm}$ is used. The instrumental noise of the used RSD 3000 unit was estimated with the method described in Burgard et al. (2006) using a dataset from an earlier remote sensing study, comprising more than 20000 on-road emission measurements on passenger cars. The detection limits were then estimated as three times the standard deviation of the noise and were determined to be $18 \mathrm{~g}$ $\left(_{\mathrm{kg} \text { fuel }}\right)^{-1}, 14 \mathrm{~g}(\mathrm{~kg} \text { fuel })^{-1}$ and $\left.5 \mathrm{~g} \mathrm{(kg} \mathrm{fuel}\right)^{-1}$ for CO, $\mathrm{HC}$ and NO, respectively.

Calibrations were conducted every $1.5-2 \mathrm{~h}$ of measurements by using a certified gas mixture containing $1510 \mathrm{ppm}$ propane, $1580 \mathrm{ppm} \mathrm{NO}, 1600 \mathrm{ppm} \mathrm{NO}_{\mathrm{x}}, 3.00 \% \mathrm{CO}$ and $12.8 \% \mathrm{CO}_{2}$ in $\mathrm{N}_{2}$ (AGA Gas). The gaseous data was retrieved from the RSD system as ppm or $\%$.

\subsection{Calculation of emission factors (EFs)}

Particle emission factors were derived by assuming the $\mathrm{CO}_{2}$ concentration to be directly proportional to the fuel consump- tion, hence assuming complete combustion. For the gaseous constituents also the measured $\mathrm{HC}$ and $\mathrm{CO}$ were accounted for. In the calculations a carbon fraction of 0.865 and 0.749 for diesel and CNG fuel, respectively, was used. In this study the emission factors are presented as mass or number per $\mathrm{kg}$ fuel used. The gaseous pollutant emission factor for each compound ( $\mathrm{CO}, \mathrm{HC}$ or $\mathrm{NO})$ per kilogram of fuel burnt was for diesel-fuelled vehicles calculated by applying Eq. (2) (Burgard et al., 2006) and for CNG-fuelled vehicles by applying Eq. (3):

$$
\begin{aligned}
& \mathrm{EF}_{\text {gas }}=\frac{\mathrm{CF}_{\text {Fuel }} \times \mathrm{SF} \times M_{\text {gas }}}{M_{\mathrm{C}}} \times \frac{\frac{\text { gas }}{\mathrm{CO}_{2}}}{\left(1+\frac{\mathrm{CO}}{\mathrm{CO}_{2}}+6 \frac{\mathrm{HC}}{\mathrm{CO}_{2}}\right)}, \\
& \mathrm{EF}_{\text {gas }}=\frac{\mathrm{CF}_{\text {Fuel }} \times \mathrm{SF} \times M_{\text {gas }}}{M_{\mathrm{C}}} \times \frac{\frac{\text { gas }}{\mathrm{CO}_{2}}}{\left(1+\frac{\mathrm{CO}}{\mathrm{CO}_{2}}+4.3 \frac{\mathrm{HC}}{\mathrm{CO}_{2}}\right)},
\end{aligned}
$$

where $\mathrm{CF}_{\text {Fuel }}$ is the carbon mass fraction of the fuels, $M_{\mathrm{gas}}$ and $M_{\mathrm{C}}$ are the molar mass of $\mathrm{CO}, \mathrm{HC}, \mathrm{NO}$ and $\mathrm{C}$, respectively, and SF is a scaling factor. The RSD unit is calibrated with propane, and the hydrocarbons in the exhaust gas from diesel vehicles are assumed to be similar to the calibration gas, hence the molar mass of propane was used as $M_{\mathrm{HC}}$ in Eq. (2). In Eq. (3) the molar mass of methane was used as this is the major constituent of CNG. The scaling factor is only applicable for determining $\mathrm{HC}$; for all the other gaseous compounds $\mathrm{SF}$ is equal to 1 . An $\mathrm{SF}$ is used to compensate for the known difference between non-dispersive infrared (NDIR)-based measurements and flame ionization detector (FID)-based measurements, a factor of 2 for diesel-fuelled vehicles (Singer et al., 1998) and a factor of 4.3 for CNGfuelled vehicles (Stephens et al., 1996; Singer et al., 1998). The factor of 6 in Eq. (2) arises from the carbon atoms per molecule of propane multiplied with the scaling factor of 2 .

Since the remote sensing device measures $\mathrm{NO}$ and not $\mathrm{NO}_{2}$, the reported $\mathrm{NO}_{\mathrm{x}}$ emission factors have been estimated from measured $\mathrm{NO}$ and the default $\mathrm{NO}_{2} / \mathrm{NO}_{\mathrm{x}}$ ratios from the HBEFA 3.1 road vehicle emission model (HBEFA3.1, 2010); see Table 2. The $\mathrm{NO}_{\mathrm{x}}$ emission factors were calculated by using Eq. (4):

$\mathrm{EF}_{\mathrm{NO}_{\mathrm{x}}}=\frac{\mathrm{EF}_{\mathrm{NO}}}{1-\left(\frac{\mathrm{NO}_{2}}{\mathrm{NO}_{\mathrm{x}}}\right)}$,

where $\mathrm{EF}_{\mathrm{NO}}$ is expressed as grams of equivalent $\mathrm{NO}_{2}$ per $\mathrm{kg}$ fuel. Reporting $\mathrm{NO}_{\mathrm{x}}$ emissions as equivalent $\mathrm{NO}_{2}$ complies with HDV emission standards (Shorter et al., 2005).

In order to be able to compare with studies expressing EFs in mass/number per $\mathrm{km}$, the EFs in this study were re-calculated by using the average fuel consumption reported for the tested diesel and CNG buses, $0.38 \mathrm{~L} \mathrm{~km}^{-1}$ and $0.735 \mathrm{Nm}^{3} \mathrm{~km}^{-1}$, respectively. For the calculations a density of $0.815 \mathrm{~kg} \mathrm{dm}^{-3}$ and $0.70 \mathrm{~kg} \mathrm{~m}^{-3}$ was assumed (Swedish Environmental Protection Agency, 2013). These EFs (in 
Table 2. HBEFA 3.1 Emission factors, fuel consumption (FC) and $\mathrm{NO}_{2}$ to $\mathrm{NO}_{\mathrm{x}}$ ratios for Ubus Std $>15-18 \mathrm{t}$ Urban Access $\operatorname{Road} / 30 /$ Stop + Go.

\begin{tabular}{|c|c|c|c|c|c|}
\hline & $\begin{array}{c}\mathrm{EF}_{\mathrm{PN}} \\
10^{14}{(\mathrm{~kg} \text { fuel })^{-1}}^{-1}\end{array}$ & $\begin{array}{c}\mathrm{EF}_{\mathrm{PM}} \\
\mathrm{g}(\mathrm{kg} \text { fuel })^{-1}\end{array}$ & $\begin{array}{c}\mathrm{EF}_{\mathrm{NO}_{\mathrm{x}}} \\
\mathrm{g}(\mathrm{kg} \text { fuel })^{-1}\end{array}$ & $\begin{array}{c}\mathrm{FC} \\
\mathrm{g} \mathrm{km}^{-1}\end{array}$ & $\begin{array}{c}\mathrm{NO}_{2} / \mathrm{NO}_{\mathrm{X}} \\
\%\end{array}$ \\
\hline Euro III & 8.3 & 0.70 & 37 & 444 & 7 \\
\hline $\begin{array}{l}\text { Euro III } \\
D P F\end{array}$ & 1.6 & 0.18 & 37 & 448 & 30 \\
\hline $\begin{array}{l}\text { Euro IV } \\
E G R\end{array}$ & 4.1 & 0.18 & 23 & 357 & 21 \\
\hline $\begin{array}{l}\text { Euro IV } \\
E G R, D P F\end{array}$ & 0.69 & 0.012 & 23 & 365 & 25 \\
\hline $\begin{array}{l}\text { Euro V } \\
E G R, D P F\end{array}$ & 0.68 & 0.012 & 14 & 372 & 25 \\
\hline $\begin{array}{l}\text { Euro V } \\
S C R\end{array}$ & 2.0 & 0.20 & 38 & 353 & 7 \\
\hline $\begin{array}{l}\text { Euro V } \\
S C R, D P F\end{array}$ & 0.20 & 0.0078 & 37 & 360 & $25^{*}$ \\
\hline CNG EEV & 0.072 & 0.17 & 44 & 510 & 25 \\
\hline
\end{tabular}

* This $\mathrm{NO}_{2} / \mathrm{NO}_{\mathrm{x}}$ ratio has also been used in this study for Euro III buses with SCR and DPF.

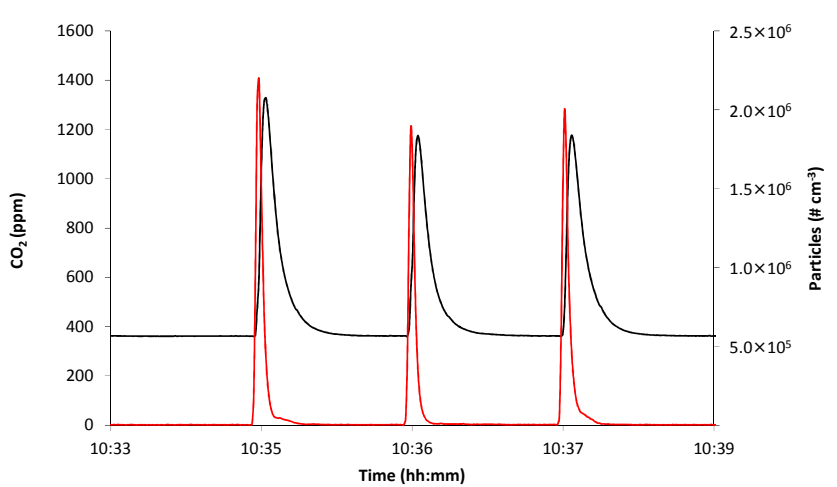

Fig. 2. Example of emission signals from three successive individual passages of the same bus in accelerating mode. Particle number (red line) and $\mathrm{CO}_{2}$ concentration (black line).

number $/ \mathrm{mass} \mathrm{km}^{-1}$ ) will be a lower limit as the fuel consumption during acceleration is expected to be higher.

\subsection{Modelling}

The measured EFs (both particles and gaseous) were also compared to modelled EFs by using the HBEFA 3.1 (2010). This model provides EFs in $\mathrm{g} \mathrm{km}^{-1}$ for six main categories of road vehicles: passenger cars, light duty vehicles, heavy goods vehicles, urban buses, coaches and motorcycles (including mopeds). These main categories are further divided into size classes, type of fuel and emission standards. For all Euro IV and Euro V HDVs the model provides EFs separately for vehicles with SCR and for vehicles with EGR. For the class urban buses EFs are also provided for vehicles both with and without DPF. Furthermore, the emission factors are given for a large number of traffic situations based on emis- sion measurements according to different sets of real-world driving cycles (HBEFA3.1, 2010).

The measured EFs in this work were compared to modelled data for a standard urban bus (15-18 tons). The driving pattern was classified according to the HBEFA 3.1 traffic situation scheme as urban access road with a posted speed of $30 \mathrm{~km} \mathrm{~h}^{-1}$ and with stop-and-go traffic. The stop-and-go traffic flow is defined as a driving cycle including many accelerations from standstill which was considered to be the driving pattern that best described the driving pattern used in the present measurements for the accelerating mode. All EFs were recalculated from $\mathrm{g} \mathrm{km}^{-1}$ to $\mathrm{g} \mathrm{kg}^{-1}$ by using the specific fuel consumption given in HBEFA 3.1. Used emission factors, fuel consumption and $\mathrm{NO}_{2}$ to $\mathrm{NO}_{\mathrm{x}}$ ratios are presented in Table 2.

\section{Results and discussion}

\subsection{Emission signal}

An example of typical signals in number of particles and $\mathrm{CO}_{2}$ concentration during a bus passage is shown in Fig. 2 . In this figure three successive bus passages for the same vehicle are displayed for the accelerating mode. The shape of the $\mathrm{CO}_{2}$ peak is broader than the particle peak, which is due to the use of a small volume before the $\mathrm{CO}_{2}$ analyser, extending the time available for the instrument to process the gas sample in order to prevent concentration peaks out of the instrument's measurement range. In Table 3 the measurement results for all the tested buses are presented. Generally there is higher variation in the data for the constant speed mode tests compared to the accelerating mode tests, which is primarily due to difficulties for the drivers to keep the same 
Table 3. $\mathrm{EF}$ for particle number $\left(\mathrm{EF}_{\mathrm{PN}}\right)$, mass $\left(\mathrm{EF}_{\mathrm{PM}}\right)$ and gaseous compounds for all the buses studied in accelerating mode (acc) and constant speed mode (const). Stated errors are at the statistical $95 \%$ confidence interval.

\begin{tabular}{|c|c|c|c|c|c|c|c|}
\hline Bus no & $\begin{array}{l}\text { Euro } \\
\text { class }\end{array}$ & $\begin{array}{c}\mathrm{EF}_{\mathrm{PN}, \mathrm{acc}} \\
\#(\mathrm{~kg} \text { fuel })^{-1} \\
10^{14}\end{array}$ & $\begin{array}{c}\mathrm{EF}_{\mathrm{PN}, \text { const }} \\
\#(\mathrm{~kg} \text { fuel })^{-1} \\
10^{14}\end{array}$ & $\begin{array}{c}\mathrm{EF}_{\mathrm{PM}}, \text { acc } \\
\mathrm{mg}(\mathrm{kg} \text { fuel })^{-1}\end{array}$ & $\begin{array}{c}\mathrm{EF}_{\mathrm{PM}} \text {, const } \\
\mathrm{mg}(\mathrm{kg} \text { fuel })^{-1}\end{array}$ & $\begin{array}{l}\mathrm{EF}_{\mathrm{CO}, \text { acc }} \\
\mathrm{g}(\mathrm{kg} \text { fuel })^{-1}\end{array}$ & $\begin{array}{l}\mathrm{EF}_{\mathrm{NO}_{\mathrm{x}}, \text { acc }}^{\mathrm{a}} \\
\mathrm{g}(\mathrm{kg} \text { fuel })^{-1}\end{array}$ \\
\hline 1 & III $^{\mathrm{b}}$ & $1.9 \pm 0.2$ & $1.1 \pm 0.2$ & $62 \pm 11$ & $41 \pm 12$ & $<18$ & $22 \pm 3$ \\
\hline 2 & III $^{\mathrm{b}}$ & $23 \pm 1^{c}$ & $9.7 \pm 0.5$ & $2465 \pm 1352^{\mathrm{c}}$ & $142 \pm 23$ & $52 \pm 10$ & $28 \pm 3$ \\
\hline 3 & III & $0.46 \pm 0.34$ & $4.2 \pm 2.6$ & $31 \pm 19$ & $273 \pm 161$ & $<18$ & $24 \pm 16$ \\
\hline 4 & III & $\mathrm{n} \cdot \mathrm{a}^{\mathrm{d}}$ & $3.4 \pm 1.0$ & $171 \pm 126$ & $151 \pm 41$ & $<18$ & $30 \pm 5$ \\
\hline 5 & III & $0.11 \pm 0.01$ & $0.12 \pm 0.04$ & $6.7 \pm 3.1$ & n.a & $<18$ & $<5^{\mathrm{e}}$ \\
\hline 6 & III & $11 \pm 2$ & n.a & $681 \pm 236$ & n.a & $<18$ & $19 \pm 2$ \\
\hline 7 & III & $33 \pm 6$ & n.a & $1566 \pm 419$ & n.a & $25 \pm 14$ & $22 \pm 7$ \\
\hline 8 & III & $45 \pm 13$ & n.a & $2074 \pm 619$ & n.a & $36 \pm 17$ & $<5$ \\
\hline 9 & IV & $13 \pm 0.1$ & $3.1 \pm 0.5$ & $650 \pm 45$ & $61 \pm 12$ & $<18$ & $<5$ \\
\hline 10 & IV & $5.1 \pm 0.6$ & $2.6 \pm 0.7$ & $177 \pm 23$ & $58 \pm 8$ & $<18$ & $20 \pm 2$ \\
\hline 11 & IV & $39 \pm 23$ & $47 \pm 42$ & $1883 \pm 908$ & 489 & $<18$ & $9 \pm 3$ \\
\hline 12 & IV & $44 \pm 7$ & n.a & $3089 \pm 818$ & n.a & $52 \pm 35$ & $<5$ \\
\hline 13 & IV & $13 \pm 8$ & $5.8 \pm 1.8$ & $562 \pm 469$ & $91 \pm 34$ & $<18$ & $19 \pm 5$ \\
\hline 14 & EEV & $173 \pm 25$ & n.a & $36 \pm 25$ & n.a & $<18$ & $9 \pm 3$ \\
\hline 15 & EEV & $45 \pm 41$ & n.a & $15 \pm 9$ & n.a & $<18$ & $43 \pm 21$ \\
\hline 16 & EEV & $1.4 \pm 1.0$ & n.a & $3.5 \pm 1.6$ & n.a & $<18$ & $59 \pm 9$ \\
\hline 17 & EEV & $155 \pm 33$ & n.a & $60 \pm 15$ & n.a & $<18$ & $77 \pm 4$ \\
\hline 18 & EEV & $144 \pm 12$ & n.a & $49 \pm 24$ & n.a & $<18$ & $89 \pm 27$ \\
\hline 19 & EEV & $11 \pm 7$ & $5.6 \pm 9.4$ & $3.0 \pm 1.4$ & $1.9 \pm 0.5$ & $<18$ & $<5$ \\
\hline 20 & EEV & $13 \pm 4$ & $20 \pm 7$ & $0.38 \pm 0.22$ & n.a & $<18$ & $<5$ \\
\hline 21 & $\mathrm{~V}$ & $2.9 \pm 0.5$ & $2.4 \pm 0.5$ & $76 \pm 14$ & $46 \pm 12$ & $<18$ & $63 \pm 5$ \\
\hline 22 & V & $4.4 \pm 1.5$ & $2.7 \pm 0.5$ & $125 \pm 52$ & $47 \pm 13$ & $<18$ & $45 \pm 5$ \\
\hline 23 & $\mathrm{~V}$ & $8.4 \pm 0.9$ & $5.2 \pm 1.7$ & $175 \pm 36$ & $63 \pm 23$ & $<18$ & $50 \pm 2$ \\
\hline 24 & V & $11 \pm 1$ & $20 \pm 4$ & $184 \pm 14$ & $204 \pm 109$ & $<18$ & $38 \pm 6$ \\
\hline 25 & $\mathrm{~V}$ & $12 \pm 1$ & $7.4 \pm 3.3$ & $242 \pm 26$ & $56 \pm 26$ & $<18$ & $27 \pm 12$ \\
\hline 26 & $\mathrm{~V}$ & $11 \pm 1$ & $12 \pm 5$ & $181 \pm 11$ & $205 \pm 147$ & $<18$ & $49 \pm 0$ \\
\hline 27 & V & $8.3 \pm 1.4$ & $4.1 \pm 0.7$ & $178 \pm 42$ & $61 \pm 15$ & $<18$ & $42 \pm 27$ \\
\hline 28 & $\mathrm{~V}$ & $15 \pm 6$ & $3.2 \pm 0.6$ & $318 \pm 167$ & $41 \pm 8$ & $<18$ & $29 \pm 11$ \\
\hline 29 & V & $0.36 \pm 0.45$ & $0.095 \pm 0.028$ & $3.8 \pm 2.8$ & $4.9 \pm 5.2$ & $<18$ & $<5$ \\
\hline 30 & $\mathrm{~V}$ & $5.8 \pm 0.5$ & $5.0 \pm 0.3$ & $298 \pm 25$ & $77 \pm 19$ & $19 \pm 21$ & $58 \pm 4$ \\
\hline 31 & $\mathrm{~V}$ & $7.6 \pm 2.9$ & $33 \pm 16$ & $240 \pm 87$ & $509 \pm 264$ & $28 \pm 9$ & $43 \pm 4$ \\
\hline 32 & $\mathrm{~V}$ & $15 \pm 6$ & $3.9 \pm 2.7$ & $766 \pm 429$ & $398 \pm 260$ & $<18$ & $20 \pm 2$ \\
\hline 33 & $\mathrm{~V}$ & $7.2 \pm 0.9$ & n.a & $232 \pm 77$ & n.a & $<18$ & $51 \pm 6$ \\
\hline 34 & $\mathrm{~V}$ & $92 \pm 42$ & n.a & $165 \pm 66$ & n.a & $<18$ & $17 \pm 20$ \\
\hline 35 & $\mathrm{~V}$ & $5.0 \pm 2.0$ & $15 \pm 5$ & $246 \pm 128$ & $385 \pm 275$ & $<18$ & $15 \pm 11$ \\
\hline
\end{tabular}

\footnotetext{
${ }^{\mathrm{a}}$ In $\mathrm{NO}_{2}$ equivalents

b Modified Euro III, now classified as Euro V

c Omitted when calculating average size distributions and total numbers

d n.a = not available

e Less than $8 \mathrm{~g}$ (kg fuel $)^{-1} \mathrm{NO}$ as $\mathrm{NO}_{2}$ equivalents.
}

constant speed/rpm while passing the measurement equipment on repeated occasions. However, vehicles identified as high-emitters in the accelerating mode were also generally identified as high-emitters in the constant speed mode (Table 3).

\section{2 $\quad \mathrm{EF}_{\text {part }}$ for different Euro classes}

In Fig. 3 the derived $\mathrm{EF}_{\mathrm{PN}}$ and $\mathrm{EF}_{\mathrm{PM}}$ for each Euro class are shown for the accelerating mode. Generally, higher EFs were obtained for buses without DPFs regarding both number and mass of particles emitted. The CNG buses emitted on average a higher number of particles compared to the diesel-fuelled buses, which is in line with previous studies (Jayaratne et al., $2008,2010)$. When comparing the average $\mathrm{EF}_{\mathrm{PN}}$ of the investigated diesel-fuelled buses with the CNG-fuelled buses for the accelerating mode, the $\mathrm{EF}_{\mathrm{PN}}$ for $\mathrm{CNG}$ buses were about five times higher $\left(1.6 \pm 0.7 \times 10^{15}\right.$ vs. $7.8 \pm 5.7 \times 10^{15}$ $(\mathrm{kg} \text { fuel })^{-1}$ ), which is similar to results obtained by Jayaratne et al. $(2008)\left(4.0 \times 10^{15}\right.$ vs. $\left.2.1 \times 10^{16}(\mathrm{~kg} \mathrm{fuel})^{-1}\right)$, when 
a)

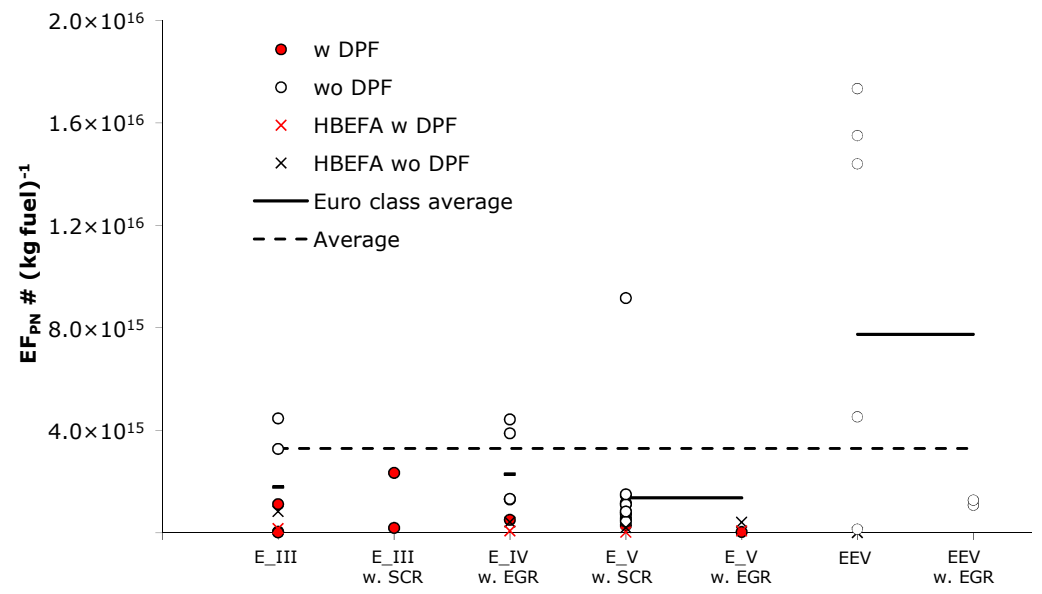

b)

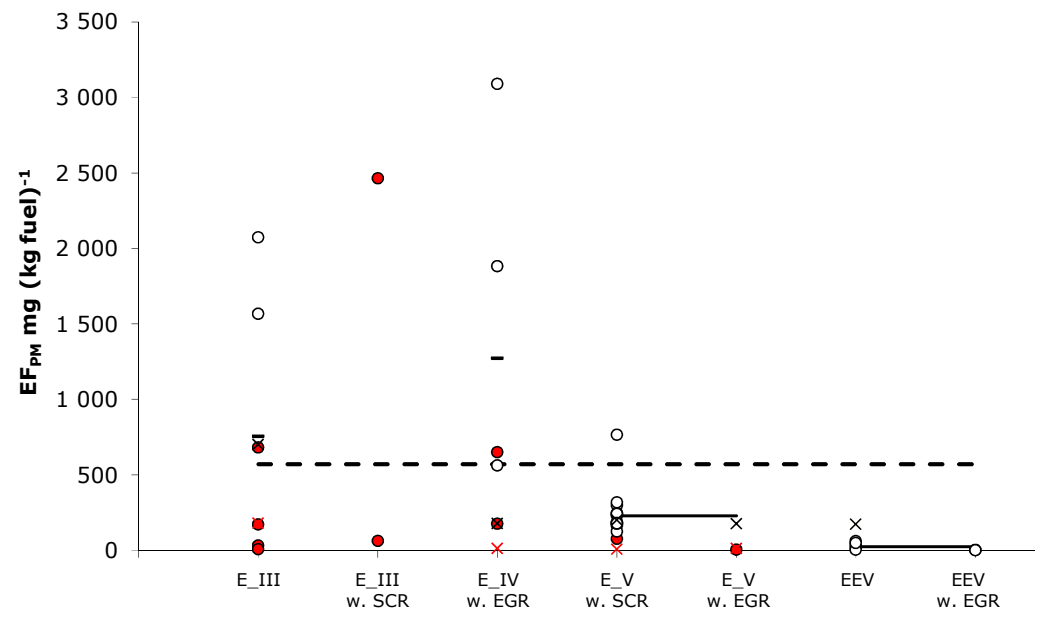

Fig. 3. $\mathrm{EF}_{\mathrm{PN}}$ (a) and $\mathrm{EF}_{\mathrm{PM}}$ (b) for all the buses studied divided into Euro class for the driving mode acceleration. Without DPF (white circles), with DPF (red circles), average of all represented Euro classes (dashed line), average of an individual represented Euro class (solid line). Crosses are EFs obtained by the HBEFA 3.1 model with DPF (red) and without (black).

using the same fuel C-content assumption as in this study. However, in the case of mass of particles, the emissions from the CNG buses were on average lower compared to diesel buses.

Figure 3 also shows that a diesel bus with DPF for the accelerating mode emits on average 5 times less than a diesel bus without DPF regarding number of particles and 3 times less regarding mass of particles $\left(4.4 \pm 3.5 \times 10^{14}\right.$ vs. $2.1 \pm 1.0 \times 10^{15} \mathrm{~kg}^{-1}$ and $206 \pm 175$ vs. $696 \pm 398 \mathrm{mg} \mathrm{kg}^{-1}$ ).

Regarding number of particles, only buses without DPF were having EFs above the average EF of all tested vehicles (see Fig. 3). The largest scatter in $\mathrm{EF}_{\mathrm{PN}}$ was, however, obtained for the CNG-fuelled buses. Out of the 15 highest PN-emitting buses, there were five gas buses (in total 7 CNG buses were tested) and 13 had no DPF installed. Regarding mass of particles, vehicles emitting above the average $\mathrm{EF}_{\mathrm{PM}}$ of all tested buses belonged to all Euro classes, except for buses representing Euro V with EGR and the CNGfuelled buses. The 15 highest PM-emitting buses were only diesel-fuelled buses; 12 had no DPF and four of the total five tested Euro IV with EGR buses were among these vehicles. The higher masses obtained for EGR-equipped buses without DPF may be due to the decrease in oxygen content when some of the exhaust gas is re-circulated, which favours soot formation (Seinfeld and Pandis, 1998; Maricq, 2007).

For comparison, modelled values of $\mathrm{EF}_{\mathrm{PN}}$ and $\mathrm{EF}_{\mathrm{PM}}$ using the HBFA 3.1 model are shown in Table 2. The modelled values are generally significantly lower than the measured values. A possible explanation for this can be different driving modes, acceleration versus route, including start and stops but also constant speed mode. As indicated by Table 3, $\mathrm{EF}_{\mathrm{PN} / \mathrm{PM}}$ was generally lower for constant speed mode compared to acceleration. Modelled $\mathrm{EF}_{\mathrm{PN}}$ was the lowest for CNG buses and highest for diesel buses, whereas the opposite was found in this study. A reason for this can be that the particle number emissions that the HBEFA model is based on often follow the PMP protocol, involving heating the particle sample to $300^{\circ} \mathrm{C}$, and the $\mathrm{CNG}$ particles are suggested to be volatile (Jayaratne et al., 2012). 
For the constant speed mode higher EFs were also generally obtained for buses without DPF. However, too few CNG buses were analysed in this driving mode to make a comparison between EFs for CNG buses and diesel buses.

Table 4 is a summary of the average $\mathrm{EF}_{\mathrm{PN}}$ and $\mathrm{EF}_{\mathrm{PM}}$ for diesel buses with and without DPF and for CNG buses obtained in this study (recalculated to $\mathrm{km}^{-1}$ ) and a comparison to other studies. Generally, the average EFs obtained for number of particles are within the reported ranges for diesel buses but somewhat higher for the CNG-fuelled buses. The average $\mathrm{EF}_{\mathrm{PM}}$ measured for diesel buses in this study are also within the ranges reported in other studies. In Table 4 most $\mathrm{EF}_{\mathrm{PM}}$ data is for larger particle size ranges. However, as most particles related to road traffic combustion are below $560 \mathrm{~nm}$, as is shown in Figs. 4 and 5, the particle size range used in this study is comparable to $\mathrm{PM}_{10}$ and $\mathrm{PM}_{2.5}$. However, important to note is that road measurements of $\mathrm{PM}_{10}$ and $\mathrm{PM}_{2.5}$ can include non-combustion-related particle emissions, e.g. re-suspension, and can hence be higher. It is a large variation in the reported data regarding the mass emitted for $\mathrm{CNG}$ buses and the data reported in this study are similar to results by Jayaratne et al. (2009) and Nylund et al. (2004).

In Lopez et al. (2009) a Euro IV diesel-fuelled bus equipped with EGR and DPF and a Euro IV diesel-fuelled bus equipped with SCR were analysed for a full driving cycle for which $\mathrm{EF}_{\mathrm{PM}}$ were determined to be $49 \pm 1$ and $73 \pm 4 \mathrm{mg}$ vehicle ${ }^{-1} \mathrm{~km}^{-1}$, respectively. In this study no Euro IV with SCR were studied, but Euro V were studied, and the average $\mathrm{EF}_{\mathrm{PM}}$ for these buses (when excluding one extreme) was $68 \pm 11 \mathrm{mg}$ vehicle $\mathrm{e}^{-1} \mathrm{~km}^{-1}$. Two Euro IV diesel-fuelled buses equipped with EGR and DPF were tested: one gave similar EFPM to Lopez et al. (2009), $55 \mathrm{mg}$ vehicle ${ }^{-1} \mathrm{~km}^{-1}$, and the other significantly higher $\mathrm{EF}_{\mathrm{PM}}, 201 \mathrm{mg}$ vehicle ${ }^{-1} \mathrm{~km}^{-1}$.

The data presented in this study (Table 3 ) is a reflection of the true variation in an in-use regional bus fleet, where the variation found between similar buses (e.g. regarding fuel type and after-treatment technology) within the same Euro class can be due to engine specifics, maintenance and malfunction.

\subsection{Size-resolved EF, number and mass}

In Fig. 4, size-resolved $\mathrm{EF}_{\mathrm{PN}}$ for each bus class in the accelerating mode are shown, i.e. diesel buses with (Fig. 4a) and without (Fig. 4b) DPF and CNG buses (Fig. 4c). All classes show more or less a unimodal number size distribution. Diesel buses emit larger particles compared to CNG buses, peak diameter $70-90 \mathrm{~nm}$ and $10 \mathrm{~nm}$, respectively, which is similar to results reported in Jayaratne et al. (2009) (80-90 nm and 10-12 nm, respectively). The lack of larger particles in the emissions from CNG-fuelled buses decreases the available surface area, hence favouring nucleation over adsorption/condensation of supersaturated vapours. This enhanced nucleation is one reason for
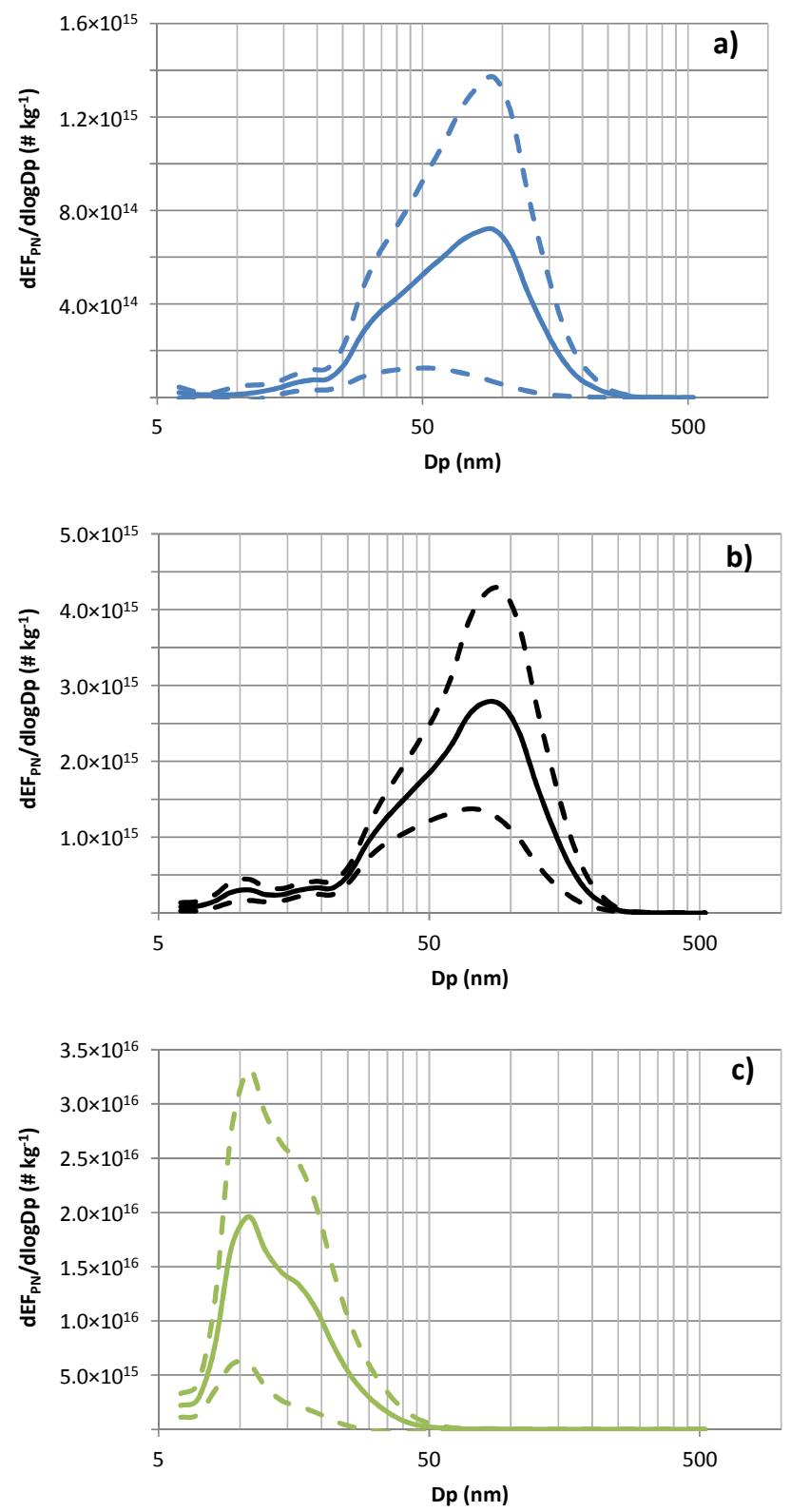

Fig. 4. Size-resolved average $\mathrm{EF}_{\mathrm{PN}}$ for diesel buses (Euro III-V) with DPF (a) and without DPF (b) and for CNG buses (c) for the driving mode acceleration. Solid lines represent averages and dashed lines the statistical $95 \%$ confidence interval. For the data presented in graph (b) one bus (no. 34) was excluded showing much higher size-resolved $\mathrm{EF}_{\mathrm{PN}}$ and with a peak size of $\sim 17 \mathrm{~nm}$.

the larger average particle number emissions for the tested CNG buses (Kumar et al., 2010). The mass size distribution shows that the diesel engines in the accelerating mode primarily emit particles with a diameter of $\sim 150 \mathrm{~nm}$ and that CNG buses exhibit on average a bimodal mass size distribution with one mode peaking at about $25 \mathrm{~nm}$ and another at $\sim 125 \mathrm{~nm}$ (Fig. 5). 
Table 4. Comparison of emission data for particle number and mass from present study with selected literature data.

\begin{tabular}{|c|c|c|c|c|c|c|}
\hline $\mathrm{PN}$ & & & & & & \\
\hline Ref & $\begin{array}{l}\text { Dp range } \\
\mathrm{nm}\end{array}$ & $\begin{array}{l}\text { Speed } \\
\mathrm{km} \mathrm{h}^{-1}\end{array}$ & Vehicle type & Method & Instrument & $\begin{array}{l}\mathrm{EF}_{\mathrm{PN}} \\
\# \text { vechicle } \\
10^{14}\end{array}$ \\
\hline \multirow[t]{3}{*}{ This study } & $5.6-560$ & acc. & bus diesel & road & EEPS & $1.4 \pm 1.1^{\mathrm{a}}$ \\
\hline & $5.6-560$ & acc. & bus diesel & road & EEPS & $6.5 \pm 3.2^{b}$ \\
\hline & $5.6-560$ & acc. & bus CNG & road & EEPS & $40 \pm 29$ \\
\hline Beddows and Harrison (2008) & $>7$ & & HDV & aggregated & $\mathrm{CPC}$ & 7.06 \\
\hline Birmili et al. (2009) & $10-500$ & $75-90$ & HDV & CFD & TDMPS & $29.6 \pm 3.5$ \\
\hline Corsmeier et al. (2005) & $30-300$ & 85 & HDV & box model & & 7.8 \\
\hline Jayaratne et al. (2010) & $>5$ & 80 & bus diesel & dynamoneter & $\mathrm{CPC}$ & 1.71 \\
\hline Jayaratne et al. (2010) & $>5$ & 80 & bus CNG & dynamoneter & $\mathrm{CPC}$ & 5.4 \\
\hline Jayaratne et al. (2009) & $5-160$ & $25-100 \%{ }^{\mathrm{c}}$ & bus diesel & dynamometer & SMPS & $1.2-18$ \\
\hline Jayaratne et al. (2009) & $5-160$ & $25-100 \% \mathrm{c}$ & bus CNG & dynamometer & SMPS & $1.0-14$ \\
\hline Jones and Harrison (2006) & $11-450$ & $<50$ & HDV & street canyon & SMPS & 6.36 \\
\hline Keogh et al. (2010) & $\mathrm{ns}^{\mathrm{d}}$ & & HDV & statistical $^{\mathrm{e}}$ & $\mathrm{CPC}$ & $65(60.19-69.81)$ \\
\hline Keogh et al. (2010) & ns & & HDV & statistical $^{\mathrm{e}}$ & SMPS & 3.08 \\
\hline Morawska et al. (2008) & $10-30$ & & HDV & review & & $2.14-37.8$ \\
\hline Morawska et al. (2008) & $18-50$ & & HDV & review & & $1.55-8.2$ \\
\hline Morawska et al. (2008) & $18-100$ & & HDV & review & & $1.7-10.5$ \\
\hline Morawska et al. (2008) & $30-100$ & & HDV & review & & 3.19 \\
\hline Wang et al. (2010) & $10-700$ & $90-110$ & HDV & road & DMPS & 17.5 \\
\hline Wang et al. (2010) & $10-700$ & $0-50$ & HDV & road & DMPS & 22.1 \\
\hline Keogh et al. (2010) & ns & & LDV & statistical $^{\mathrm{e}}$ & $\mathrm{CPC}$ & 3.63 \\
\hline \multicolumn{7}{|l|}{$\mathrm{PM}$} \\
\hline Ref & $\operatorname{PM}(x)$ & $\begin{array}{l}\text { Speed } \\
\mathrm{km} \mathrm{h}^{-1}\end{array}$ & Vehicle type & Method & Instruments & 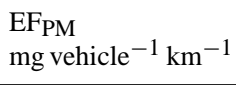 \\
\hline \multirow[t]{3}{*}{ This study } & $5.6-560$ & acc. & bus diesel & road & EEPS & $64 \pm 54^{\mathrm{a}}$ \\
\hline & $5.6-560$ & acc. & bus diesel & road & EEPS & $215 \pm 123^{b}$ \\
\hline & $5.6-560$ & acc. & bus $\mathrm{CNG}$ & road & EEPS & $12 \pm 9$ \\
\hline Clark et al. (1999) & $\mathrm{PM}$ & d.c & bus diesel & dynamometer & ns & $190-1450$ \\
\hline Clark et al. (1999) & PM & d.c & bus CNG & dynamometer & ns & $4-100$ \\
\hline Jayaratne et al. (2009) & $\mathrm{PM}_{10}$ & $25-100 \%{ }^{\mathrm{c}}$ & bus diesel & dynamometer & DustTrak & $46.5-668.6$ \\
\hline Jayaratne et al. (2009) & $\mathrm{PM}_{10}$ & $25-100 \% \mathrm{c}$ & bus CNG & dynamometer & DustTrak & $0.01-1.3$ \\
\hline Jones and Harrison (2006) & $\mathrm{PM}_{10}$ & $<50$ & HDV & street canyon & TEOM & $370 \pm 32$ \\
\hline Jones and Harrison (2006) & $\mathrm{PM}_{2.5}$ & $<50$ & HDV & street canyon & TEOM & $179 \pm 22$ \\
\hline Keogh et al. (2010) & $\mathrm{PM}_{10}$ & Ns & HDV & statistical $^{\mathrm{e}}$ & several & 538 \\
\hline Keogh et al. (2010) & $\mathrm{PM}_{2.5}$ & Ns & HDV & statistical $^{\mathrm{e}}$ & several & $302(236-367)$ \\
\hline Lanni et al. (2003) & $\mathrm{PM}$ & d. $c^{f}$ & bus diesel & dynamometer & gravimetric & 72 \\
\hline Lanni et al. (2003) & $\mathrm{PM}$ & d.c & bus $\mathrm{CNG}$ & dynamometer & gravimetric & 86 \\
\hline Lopez et al. (2009) & $\mathrm{PM}$ & d.c & bus EIV EGR + DPF & on-board & MAHA & $49 \pm 1^{g}$ \\
\hline Lopez et al. (2009) & PM & d.c & bus EIV SCR & on-board & MAHA & $73 \pm 4^{g}$ \\
\hline Nylund et al. (2004) & $\mathrm{PM}$ & d.c & bus diesel & dynamometer & ns & $20-170$ \\
\hline Nylund et al. (2004) & PM & d.c & bus $\mathrm{CNG}$ & dynamometer & ns & $5-10$ \\
\hline Ullman et al. (2003) & $\mathrm{PM}$ & d.c & bus diesel & dynamometer & gravimetric & 296 \\
\hline Ullman et al. (2003) & $\mathrm{PM}$ & d.c & bus CNG & dynamometer & gravimetric & 84 \\
\hline Wang et al. (2010) & $\mathrm{PM}_{2.5}$ & $90-110$ & HDV & road $^{\mathrm{h}}$ & TEOM & $233 \pm 18$ \\
\hline Wang et al. (2010) & $\mathrm{PM}_{2.5}$ & $0-50$ & HDV & $\operatorname{road}^{\mathrm{i}}$ & TEOM & $628 \pm 50$ \\
\hline Wang et al. (2010) & $\mathrm{PM}_{10}$ & $90-110$ & HDV & $\operatorname{road}^{\mathrm{h}}$ & TEOM & $1087 \pm 68$ \\
\hline Wang et al. (1997) & PM & d.c & bus diesel & dynamoneter & gravimetric & 1960 \\
\hline Wang et al. (1997) & $\mathrm{PM}$ & d.c & bus $\mathrm{CNG} / \mathrm{LNG}$ & dynamometer & gravimetric & 48 \\
\hline Keogh et al. (2010) & $\mathrm{PM}_{10}$ & Ns & LDV & statistical $^{\mathrm{e}}$ & several & 153 \\
\hline Keogh et al. (2010) & $\mathrm{PM}_{2.5}$ & Ns & LDV & statistical $^{\mathrm{e}}$ & several & 33 \\
\hline
\end{tabular}


Table 5. Comparison of emission data for $\mathrm{NO}_{\mathrm{x}}$, VOC and $\mathrm{CO}$ from present study with selected literature data.

\begin{tabular}{|c|c|c|c|c|c|c|}
\hline Ref & $\begin{array}{l}\text { Speed } \\
\mathrm{km} \mathrm{h}^{-1}\end{array}$ & Vehicle type & Method & $\begin{array}{l}\mathrm{EF}_{\mathrm{NO}_{\mathrm{x}}} \\
\mathrm{g} \mathrm{km}^{-1}\end{array}$ & $\begin{array}{l}\mathrm{EF}_{\text {VOC }} \\
\mathrm{g} \mathrm{km}^{-1}\end{array}$ & $\begin{array}{l}\mathrm{EFCO}_{\mathrm{CO}} \\
\mathrm{g} \mathrm{km}^{-1}\end{array}$ \\
\hline \multirow[t]{4}{*}{ This study } & acc & Euro III & road & $5 \pm 3$ & $<4^{\mathrm{a}}$ & $5 \pm 5$ \\
\hline & acc & Euro IV & road & $4 \pm 2$ & $<4^{\mathrm{a}}$ & $5 \pm 5$ \\
\hline & acc & Euro V & road & $11 \pm 3$ & $<4^{\mathrm{a}}$ & $3 \pm 1$ \\
\hline & acc & CNG bus & road & $21 \pm 14$ & $<4^{\mathrm{a}}$ & $<3$ \\
\hline Chen et al. (2007) & $<85$ & HDV & on-board & 6.54 & 1.88 & 4.96 \\
\hline Clark et al. (1999) & d.c $\mathrm{c}^{\mathrm{b}}$ & bus diesel & dynamometer & $28.5-37.5$ & $0.1-0.6^{\mathrm{c}}$ & $2.5-18.0$ \\
\hline Clark et al. (1999) & d.c & bus $\mathrm{CNG}$ & dynamometer & $10.9-23.8$ & $16.9-32.2^{\mathrm{c}}$ & $0.2-13.3$ \\
\hline Corsmeier et al. (2005) & 85 & HDV & on-road & $6.86 \pm 1.57$ & - & - \\
\hline Jayaratne et al. (2009) & $25-100 \%$ & bus diesel & dynamometer & $6.7-18$ & - & - \\
\hline Jayaratne et al. (2009) & $25-100 \%$ & bus $\mathrm{CNG}$ & dynamometer & $5.5-32$ & - & - \\
\hline Jones and Harrison (2006) & $<50$ & HDV & street canyon & 5.19 & - & - \\
\hline Kristensson et al. (2004) & 75 & HDV & tunnel & $8.0 \pm 0.8$ & - & - \\
\hline Lanni et al. (2003) & d.c & bus diesel DPF & dynamometer & 38.4 & 0.1 & 0.2 \\
\hline Lanni et al. (2003) & d.c & bus $\mathrm{CNG}$ & dynamometer & 68.9 & 93.9 & 76.4 \\
\hline Lopez et al. (2009) & d.c & bus EIV EGR + DPF & on-board & 6.925 & $0.068^{c}$ & 0.250 \\
\hline Lopez et al. (2009) & d.c & bus EIV SCR & on-board & 6.121 & $0.053^{\mathrm{c}}$ & 1.716 \\
\hline Nylund et al. (2004) & d.c & bus diesel & dynamometer & $8-9$ & $0.05-0.4^{\mathrm{c}}$ & - \\
\hline Nylund et al. (2004) & d.c & bus CNG & dynamometer & $2-7$ & $0.25-2^{\mathrm{c}}$ & - \\
\hline Ullman et al. (2003) & d.c & bus diesel & dynamometer & 22.7 & 0.6 & 2.8 \\
\hline Ullman et al. (2003) & d.c & bus CNG & dynamometer & 26.1 & 15.0 & 7.7 \\
\hline Wang et al. (2010) & 90 & HDV & on-road & $9.8 \pm 0.29$ & - & - \\
\hline Wang et al. (2010) & $0-50$ & HDV & on-road & $11.9 \pm 0.59$ & - & - \\
\hline Wang et al. (2008) & & bus & calculated $^{\mathrm{d}}$ & 18.19 & 3.71 & 37.15 \\
\hline Wang et al. (2008) & & truck & calculated $^{\mathrm{d}}$ & 9.3 & 2.99 & 34.79 \\
\hline
\end{tabular}

For the analysis of the average size-resolved $\mathrm{EF}_{\mathrm{PN} / \mathrm{PM}}$ for buses without DPF (Figs. 4b and 5b), one bus (no. 34) was excluded showing much higher size-resolved EFPN and with a peak size of $\sim 17 \mathrm{~nm}$. For this bus the average size-resolved $\mathrm{EF}_{\mathrm{PM}}$ was bimodal with peak sizes of $\sim 30 \mathrm{~nm}$ and $\sim 190 \mathrm{~nm}$. The reason for this discrepancy is not known but could be due to maintenance or malfunction of this particular bus.

For the constant speed mode the characteristic bimodal number size distributions were obtained for the diesel buses with and without DPF, with one mode peaking at $\sim 10 \mathrm{~nm}$ (nucleation mode) and the other at $\sim 60 \mathrm{~nm}$ (soot mode/accumulation mode) (Fig. 6) (Maricq, 2007). The reason for the different average number size distributions between accelerating and constant speed mode may be more available surface area in the accelerating mode, hence favouring adsorption/condensation over nucleation. In acceleration from standstill the engine load is close to its maximum, and Jayaratne et al. (2009) also obtained a unimodal number size distribution for a diesel bus at $100 \%$ load.

\subsection{Comparison of $\mathrm{EF}_{\text {part }}$ and $\mathrm{EF}_{\text {gas }}\left(\mathrm{NO}_{\mathrm{x}}, \mathrm{HC}\right.$ and $\left.\mathrm{CO}\right)$}

The highest $\mathrm{NO}_{\mathrm{x}}$ values were obtained for the CNG buses compared to all the other Euro classes of diesel buses; however, the scatter was largest for the CNG buses as well $\left(41 \pm 26 \mathrm{~g} \mathrm{~kg}^{-1}\right)$ (Fig. 7), which is in accordance with Ekström et al. (2005). Possible reasons for this variability may be vehicle maintenance and variations in the CNG composition (Shorter et al., 2005; Ayala et al., 2002). The EF for $\mathrm{NO}_{\mathrm{x}}$ ranged from 4 to $21 \mathrm{~g} \mathrm{~km}^{-1}$ depending on Euro class, which is in good agreement with reported values for HDVs and buses in the literature (Table 5). In comparison with the HBEFA 3.1 model, the measured values for $\mathrm{EF}_{\mathrm{NO}_{\mathrm{x}}}$ are on average lower for all the tested Euro classes but within the $95 \%$ confidence interval for the Euro V with SCR and EEV buses. However, for some SCR-equipped buses and CNG buses higher $\mathrm{EF}_{\mathrm{NO}_{\mathrm{x}}}$ values were measured. One reason for some of the high values regarding SCR may be that it is critical that the exhaust temperature is high enough for the SCR to work properly.

In Fig. 8a there is a comparison of $\mathrm{EF}_{\text {part }}$ and $\mathrm{EF}_{\mathrm{NO}_{\mathrm{x}}}$; both mass and number of particles show an anti-relationship with $\mathrm{NO}_{\mathrm{x}}$, which is especially true when no DPF is installed. In a 

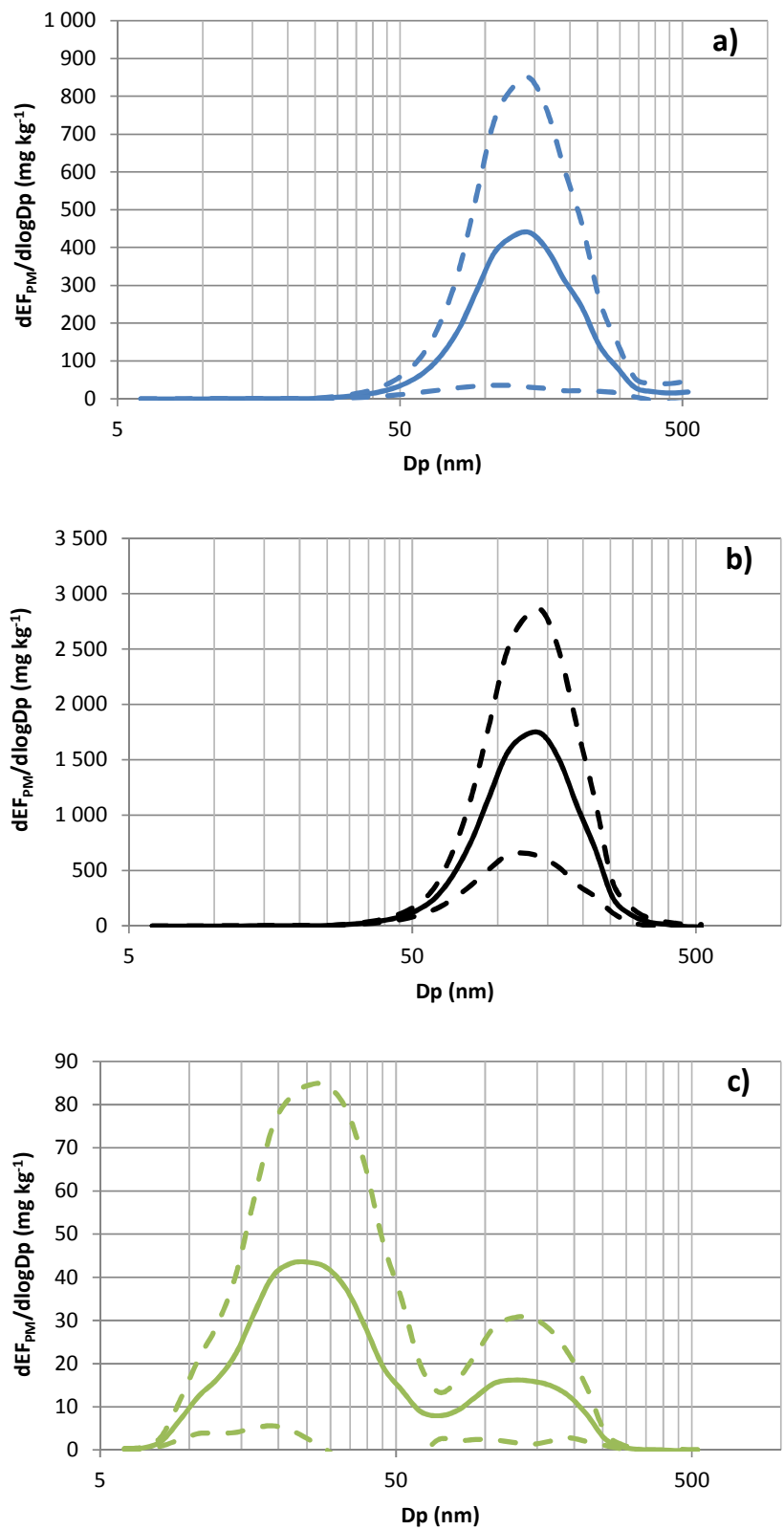

Fig. 5. Size-resolved average $\mathrm{EF}_{\mathrm{PM}}$ for diesel buses (Euro III-V) with DPF (a) and without DPF (b) and for CNG buses (c) for the driving mode acceleration. Solid lines represent averages and dashed lines the statistical $95 \%$ confidence interval. For the data presented in graph (b) one bus (no. 34) was excluded showing a bimodal $\mathrm{EF}_{\mathrm{PM}}$ and with peak sizes of $\sim 30 \mathrm{~nm}$ and $\sim 190 \mathrm{~nm}$.

diesel engine there is a compromise between emissions of $\mathrm{NO}_{\mathrm{x}}$ and emissions of particles (Clark et al., 1999), as is demonstrated by the data in Fig. 8a. For the CNG-fuelled buses no such trend was observed.

Generally the emission of $\mathrm{CO}$ from a diesel engine is low as the combustion is carried out in an air-rich environment. This can be seen in the data for the tested buses, where the $\mathrm{CO}$ concentrations for many of the buses are below the de-
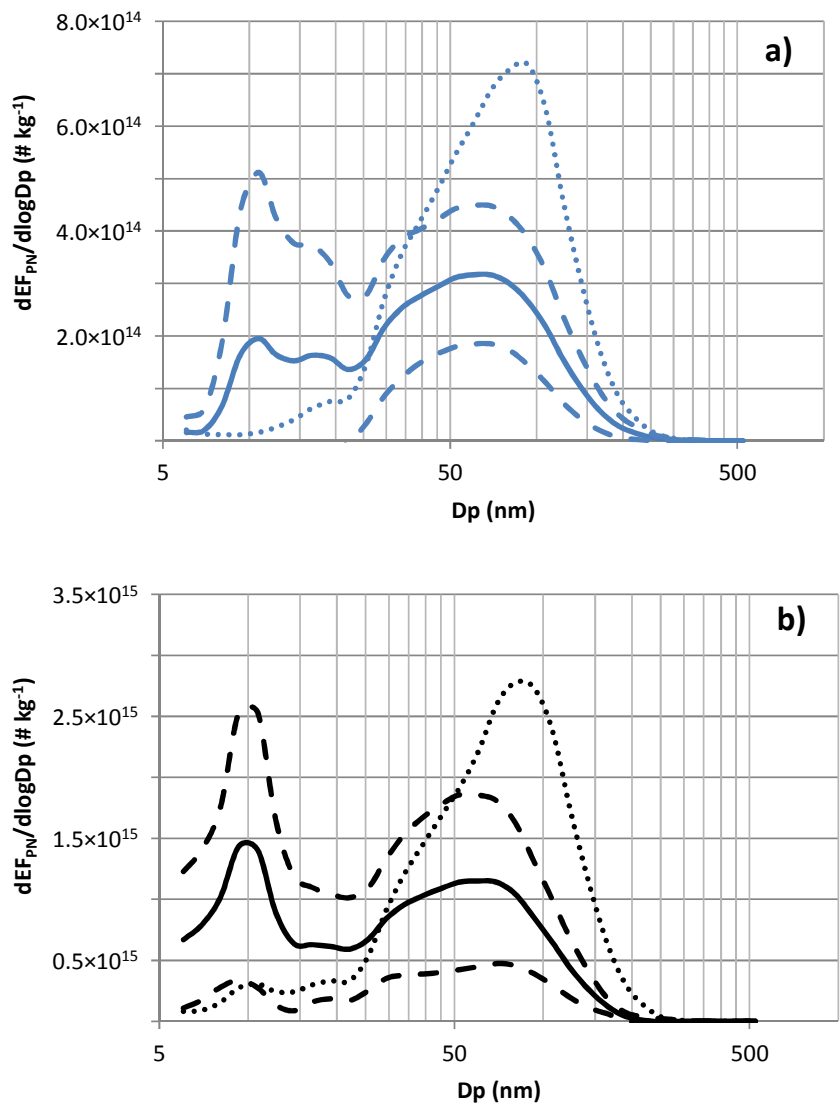

Fig. 6. Size-resolved average $\mathrm{EF}_{\mathrm{PN}}$ for diesel buses (Euro III-V) with DPF (a) and without DPF (b) for the driving mode constant speed mode. Solid lines represent averages and dashed lines the statistical $95 \%$ confidence interval. Dotted lines represent averages for the accelerating mode.

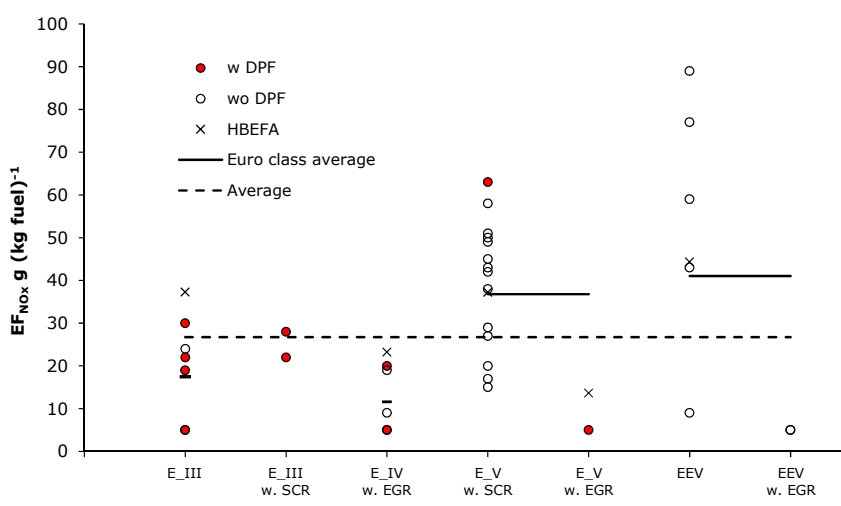

Fig. 7. $\mathrm{EF}_{\mathrm{NO}_{\mathrm{x}}}$ for all the buses studied divided into Euro class. Without DPF (white circles), with DPF (red circles), average of all represented Euro classes (dashed line), average of an individual represented Euro class (solid line). Crosses are EFs obtained by the HBEFA 3.1 model. 
a)
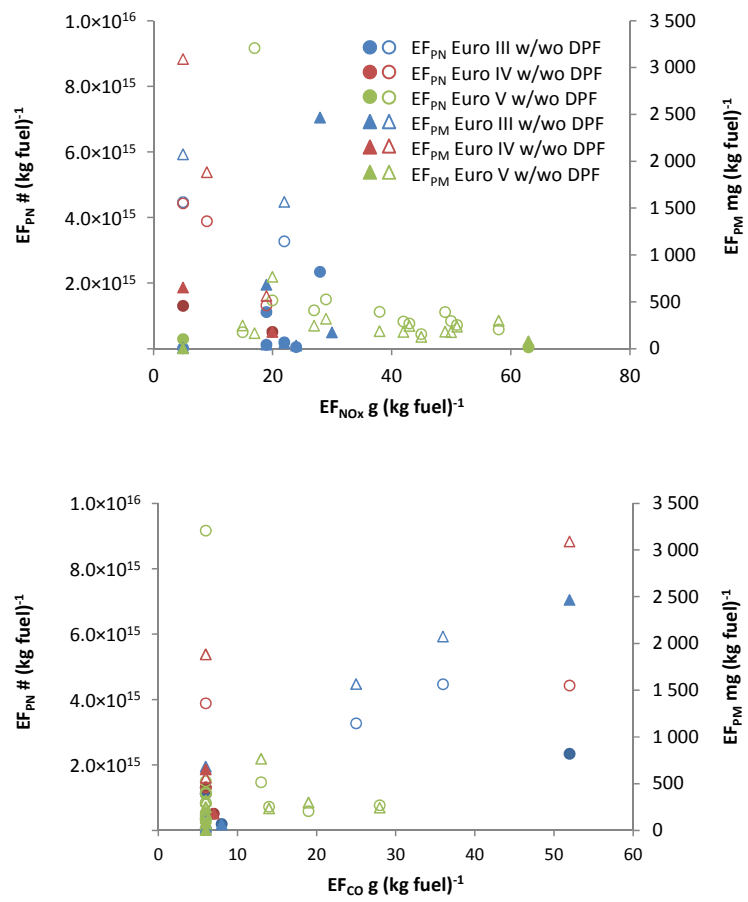

Fig. 8. $\mathrm{EF}_{\mathrm{PN}}$ (circles) and $\mathrm{EF}_{\mathrm{PM}}$ (triangles) versus the $\mathrm{EF}$ for $\mathrm{NO}_{\mathrm{x}}$ (a) and versus the $\mathrm{EF}$ for $\mathrm{CO}$ (b). Euro III (blue symbols), Euro IV (red symbols) and Euro V (green symbols). Filled symbols represent buses with DPF installed and unfilled symbols no DPF.

tection limit of the instrument (i.e. below $18 \mathrm{~g}(\mathrm{~kg} \text { fuel })^{-1}$ ). However, for six of the buses $\mathrm{CO}$ concentrations were measured ( 3 times the std of the noise). In Fig. $8 b$ the $\mathrm{EF}_{\mathrm{PM}}$ and $\mathrm{EF}_{\mathrm{CO}}$ are compared, and as is shown a positive relationship between $\mathrm{EF}_{\mathrm{PM}}$ and $\mathrm{EF}_{\mathrm{CO}}$ was observed. High $\mathrm{CO}$ concentration is an indication of incomplete combustion, hence favouring soot formation, i.e. high $\mathrm{EF}_{\mathrm{PM}}$. Regarding number of particles there is also a positive relationship, however less profound (Fig. 8b) than the relationship between $\mathrm{EF}_{\mathrm{PM}}$ and $\mathrm{EF}_{\mathrm{CO}}$.

The $\mathrm{CO}$ emissions are also influenced by DPF. The average $\mathrm{EF}_{\mathrm{CO}}$ for the diesel buses with DPF tested in this study, when assigning values below 6 (1 times the std of the noise) to $6 \mathrm{~g}$ ( $\mathrm{kg}$ fuel $)^{-1}$, were $11 \mathrm{~g}$ ( $\mathrm{kg}$ fuel $)^{-1}$ (10 buses in total). For the buses without DPF the average $\mathrm{EF}_{\mathrm{CO}}$ was $14 \mathrm{~g}$ (kg fuel) $)^{-1}$ (18 buses in total); hence DPF is not only reducing particles but $\mathrm{CO}$ as well, as reported in Ayala et al. (2002) and Lanni et al. (2001). For the tested buses, DPF had no statistical significant effect on the amount of $\mathrm{NO}_{\mathrm{x}}$ emitted, which also is in agreement with results reported by Ayala et al. (2002).

Regarding total hydrocarbon (HC), emissions above the detection limit $\left(14 \mathrm{~g}(\mathrm{~kg} \text { fuel })^{-1}\right)$ were not found for any of the buses in this study. Compared to the literature data shown in Table 5, values above the detection limit of our instrumentation were only reported for some CNG-fuelled buses.

\section{Atmospheric implications and conclusions}

The method of using a high time resolution particle instrument and $\mathrm{CO}_{2}$ concentration as a tracer of the combustion source for determining $\mathrm{EF}_{\mathrm{PN}}$ and $\mathrm{EF}_{\mathrm{PM}}$ from individual vehicles for real-world dilution showed to be very successful regarding reproducibility, costs and number of vehicles studied. This method enabled measurements of not only particle number but also size, as well as mass.

Compressed natural gas buses are more advantageous regarding emissions of particle mass compared to diesel buses. However, in accelerating mode, generally CNG buses emit more particles by number compared to diesel-fuelled buses, and these particles are smaller $\left(D_{\mathrm{p}} \sim 10 \mathrm{~nm}\right.$ compared to $\sim 80 \mathrm{~nm}$ ) and presumably more volatile. The fact that CNG buses emit high number of particles in accelerating mode, e.g. at bus stops where many people may be standing waiting for buses, is an important aspect. However, the health impact of these particles versus diesel particles is still a matter of discussion.

This study shows that DPF markedly reduces emissions of particles both by mass and number as well as $\mathrm{CO}$ emissions also for real-world dilution. Reducing the number of soot mode particles does not cause a severe increase in nucleation mode particles as is the case for some of the tested CNG-fuelled vehicles without particle filter.

There was a large variation in $\mathrm{NO}_{\mathrm{x}}$ emissions from the tested SCR-equipped buses. This is most likely due to differences in engine and exhaust temperature, which influence the efficiency of the SCR to reduce $\mathrm{NO}_{\mathrm{x}}$ emissions. In particular this has implications for $\mathrm{NO}_{2}$ population exposure in urban areas and is thus a health issue that needs to be investigated further.

Compared to other types of vehicles, the average $\mathrm{EF}_{\mathrm{PN}}$ for a diesel-fuelled bus without DPF is very similar to results obtained for a diesel passenger car without DPF (Hak et al., 2009) when looking at the number of particles emitted per kg fuel used $\left(2.1 \pm 1.0 \times 10^{15} \mathrm{~kg}^{-1}\right.$ vs. $\left.2.1 \pm 0.3 \times 10^{15} \mathrm{~kg}^{-1}\right)$. The mean $\mathrm{EF}_{\mathrm{PN}}$ for DPF-equipped diesel-fuelled buses were in the same order as an old petrol car $\left(4.4 \pm 3.5 \times 10^{14} \mathrm{~kg}^{-1}\right.$ vs. $4.2 \pm 3.0 \times 10^{14} \mathrm{~kg}^{-1}$ ) (Hak et al., 2009). However, when taking fuel consumption into consideration, there was a large difference. Diesel-fuelled buses without DPF are then emitting more particles per $\mathrm{km}^{-1}$ than a diesel passenger car without DPF, whereas DPF-equipped diesel buses are similar to a diesel passenger car without DPF $\left(6.5 \pm 3.2 \times 10^{14}\right.$ and $1.4 \pm 1.1 \times 10^{14} \mathrm{~km}^{-1}$ vs. $\left.1.2 \pm 0.2 \times 10^{14} \mathrm{~km}^{-1}\right)$. On average the CNG-fuelled bus investigated in this study emitted a higher number of particles than a diesel passenger car both with respect to $\mathrm{kg}$ fuel burnt and per $\mathrm{km}$ driven.

In the data the typical trade-off trend between emission of $\mathrm{NO}_{\mathrm{x}}$ and particles (PN and $\mathrm{PM}$ ) was observed, especially for vehicles without DPF, as well as a positive relationship between emissions of $\mathrm{CO}$ and $\mathrm{PM} / \mathrm{PN}$. 
The data presented in this study demonstrate the variation in gas and particle emissions of the in-use fleet of a regional public bus service, where variations found between similar buses can be due to engine specifics, maintenance or malfunction.

Acknowledgements. This work was financed by Västtrafik, the Foundation for the Swedish Environmental Research Institute, and the Graduate School Environment and Health, the University of Gothenburg. The drivers and the personnel at the measurement sites are gratefully acknowledged for their assistance and hospitality. Donald H. Stedman and Gary Bishop of Denver University are acknowledged for valuable input regarding the RSD evaluation.

Edited by: T. Petäjä

\section{References}

Ayala, A., Kado, N. Y., Okamoto, R. A., Holmen, B. A., Kuzmicky, P. A., Kobayashi, R., and Stiglitz, K. E.: Diesel and cng heavyduty transit bus emissions over multiple driving schedules: Regulated pollutants and project overwiew, SAE Technical Paper Series, 2002-01-1722, 2002.

Ban-Weiss, G. A., Lunden, M. M., Kirchstetter, T. W., and Harley, R. A.: Size-resolved particle number and volume emission factors for on-road gasoline and diesel motor vehicles, J. Aerosol Sci., 41, 5-12, 2010.

Beddows, D. C. S. and Harrison, R. M.: Comparison of average particle number emission factors for heavy and light duty vehicles derived from rolling chassis dynamometer and field studies, Atmos. Environ., 42, 7954-7966, doi:10.1016/j.atmosenv.2008.06.021, 2008.

Birmili, W., Alaviippola, B., Hinneburg, D., Knoth, O., Tuch, T., Borken-Kleefeld, J., and Schacht, A.: Dispersion of trafficrelated exhaust particles near the Berlin urban motorway estimation of fleet emission factors, Atmos. Chem. Phys., 9, 2355-2374, doi:10.5194/acp-9-2355-2009, 2009.

Burgard, D. A., Bishop, G. A., Stadtmuller, R. S., Dalton, T. R., and Stedman, D. H.: Spectroscopy applied to mobile source emissions, Appl. Spectrosc., 60, 135A-148A, 2006.

Canagaratna, M. R., Jayne, J. T., Ghertner, D. A., Herndon, S., Shi, Q., Jimenez, J. L., Silva, P. J., Williams, P., Lanni, T., Drewnick, F., Demerjian, K. L., Kolb, C. E., and Worsnop, D. R.: Chase studies of particulate emissions from in-use new york city vehciles, Aerosol Sci. Technol., 38, 555-573, 2004.

Chen, C. H., Huang, C., Jing, Q. G., Wang, H. K., Pan, H. S., Li, L., Zhao, J., Dai, Y., Huang, H. Y., Schipper, L., and Streets, D. G.: On-road emission characteristics of heavy-duty diesel vehicles in shanghai, Atmos. Environ., 41, 5334-5344, doi:10.1016/j.atmosenv.2007.02.037, 2007.

Clark, N. N., Gautam, M., Rapp, B. L., Lyons, D. W., Graboski, M. S., McCormick, L., Alleman, T. L., and Norton, P.: Diesel and cng transit bus emissions characterization by two chassis dynamometer laboratories: Results and issues, Soc. Autom. Eng., 1999-01-1469, 1999.

Corsmeier, U., Imhof, D., Kohler, M., Kuhlwein, J., Kurtenbach, R., Petrea, M., Rosenbohm, E., Vogel, B., and Vogt,
U.: Comparison of measured and model-calculated realworld traffic emissions, Atmos. Environ., 39, 5760-5775, doi:10.1016/j.atmosenv.2005.06.048, 2005.

Delfino, R. J., Sioutas, C., and Malik, S.: Potential role of ultrafine particles in associations between airborne particle mass and cardiovascular health, Environ. Health Perspect., 113, 934-946, doi:10.1289/ehp.7938, 2005.

Donaldson, K. Li, X. Y., and MacNee, W.: Ultrafine (nanometre) particle mediated lung injury, J. Aerosol Sci., 29, 553-560, 1998.

Ekström, M., Sjödin, Å., and Adréasson, K.: On-road optical remote sensing measurements of in-use bus emissions, 14th International Symposium Transport and Air Pollution, Graz, Austria, 2005 ,

Hak, C. S., Hallquist, M., Ljungström, E., Svane, M., and Pettersson, J. B. C.: A new approach to in-situ determination of roadside particle emission factors of individual vehicles under conventional driving conditions, Atmos. Environ., 43, 2481-2488, doi:10.1016/j.atmosenv.2009.01.041, 2009.

Hallquist, M., Wenger, J. C., Baltensperger, U., Rudich, Y., Simpson, D., Claeys, M., Dommen, J., Donahue, N. M., George, C., Goldstein, A. H., Hamilton, J. F., Herrmann, H., Hoffmann, T., Iinuma, Y., Jang, M., Jenkin, M. E., Jimenez, J. L., Kiendler-Scharr, A., Maenhaut, W., McFiggans, G., Mentel, Th. F., Monod, A., Prévôt, A. S. H., Seinfeld, J. H., Surratt, J. D., Szmigielski, R., and Wildt, J.: The formation, properties and impact of secondary organic aerosol: current and emerging issues, Atmos. Chem. Phys., 9, 5155-5236, doi:10.5194/acp-9-51552009, 2009.

Harrison, R., Jones, M., and Collins, G.: Measurements of the physical properties of particles in the urban atmopshere, Atmos. Environ., 33, 309-321, 1999.

HBEFA3.1: available online at: www.hbefa.net (last access: 13 May 2013), 2010.

Janhall, S. and Hallquist, M.: A novel method for determination of size-resolved, submicrometer particle traffic emission factors, Environ. Sci. Technol., 39, 7609-7615, 2005.

Janhall, S., Jonsson, Å. M., Molnar, P., Svensson, E. A., and Hallquist, M.: Size resolved traffic emission factors of submicrometer particles, Atmos. Environ., 38, 4331-4340, 2004.

Jayaratne, E. R., Morawska, L., Ristovski, Z. D., and Johnson, G. R.: The use of carbon dioxide as a tracer in the determination of particle number emissions from heavy-duty diesel vehicles, Atmos. Environ., 39, 6812-6821, 2005.

Jayaratne, E. R., He, C., Ristovski, Z. D., Morawska, L., and Johnson, G. R.: A comparative investigation of ultrafine particle number and mass emissions from a fleet of on-road diesel and cng buses, Environ. Sci. Technol., 42, 6736-6742, 2008.

Jayaratne, E. R., Ristovski, Z. D., and Morawska, L.: Particle and gaseous emissions from compressed natural gas and ultralow sulphur diesel-fuelled buses at four steady engine loads, Sci. Total Enivron., 407, 2845-2852, 2009.

Jayaratne, E. R., Meyer, N. K., Ristovski, Z. D., Morawska, L., and Miljevic, B.: Critical analysis of high particle number emissions from accelerating compressed natural gas buses, Environ. Sci. Technol., 44, 3724-3731, doi:10.1021/es1003186, 2010.

Jayaratne, E. R., Meyer, N. K., Ristovski, Z. D., and Morawska, L.: Volatile properties of particles emitted by compressed natural gas and diesel buses during steady-state and transient driving modes, Environ. Sci. Technol., 46, 196-203, 2012. 
Jones, A. M. and Harrison, R. M.: Estimation of the emission factors of particle number and mass fractions from traffic at a site where mean vehicle speeds vary over short distances, Atmos. Environ., 40, 7125-7137, doi:10.1016/j.atmosenv.2006.06.030, 2006.

Keogh, D. U., Kelly, J., Mengersen, K., Jayaratne, R., Ferreira, L., and Morawska, L.: Derivation of motor vehicle tailpipe particle emission factors suitable for modelling urban fleet emissions and air quality assessments, Environ. Sci. Poll. Res., 17, 724-739, doi:10.1007/s11356-009-0210-9, 2010.

Kristensson, A., Johansson, C., Westerholm, R., Swietlicki, E., Gidhagen, L., Wideqvist, U., and Vesely, V.: Real-world traffic emission factors of gases and particles measured in a road tunnel in stockholm, sweden, Atmos. Environ., 38, 657-673, doi:10.1016/j.atmosenv.2003.10.030, 2004.

Kumar, P., Robins, A., Vardoulakis, S., and Britter, R.: A review of the characteristics of nanoparticles in the urban atmosphere and the prospects for developing regulatory controls, Atmos. Environ., 44, 5035-5052, 2010.

Lanni, T., Frank, B. P., Tang, S., Rosenblatt, D., and Lowell, D.: Performance and emissions evaluation of conpressed natural gas and clean diesel buses at new york city's metropolitan transit authority, SAE Technical Paper Series, 2003-01-0300, 2003.

Lopez, J. M., Jimenez, F., Aparicio, F., and Flores, N.: On-road emissions form urban buses wiht scr+urea and egr+dpf systems uisng diesel and biodiesel, Transport. Res. Part D, 14, 1-5, 2009.

Maricq, M. M.: Chemical characterization of particulate emissions form diesel engines: A review, J. Aerosol Sci., 38, 1079-1118, 2007.

Morawska, L., Ristovski, Z., Jayaratne, E. R., Keogh, D. U., and Ling, X.: Ambient nano and ultrafine particles from motor vehicle emissions: Characteristics, ambient processing and implications on human exposure, Atmos. Environ., 42, 8113-8138, doi:10.1016/j.atmosenv.2008.07.050, 2008.

Norman, A. A., Kado, Y., Okamoto, R. A., Holmen, B. A., Kuzmicky, P. A., Kobayashi, R., and Stiglitz, K. E.: Diesel and cng heavy-duty transit bus emissions over multiple driving schedules: Regulated pollutants and project overwiew, SAE Technical Paper Series, 2002-01-1722, 2002.

Nylund, N., Erkkilä, K., Lappi, M., and Ikonen, M.: Transit bus emission study: Comparison of emissions from diesel and natural gas buses, Research report PRO3/P5150/04, 2004.

Pirjola, L., Parviainen, H., Hussein, T., Valli, A., Hämeri, K., Aaalto, P., Virtanen, A., Keskinen, J., Pakkanen, T. A., Mäkelä, T., and Hillamo, R. E.: "sniffer"-a novel tool for chasing vehicles and measuring traffic pollutants, Atmos. Environ., 38, 36253635, 2004.

Pope, C. A. and Dockery, D. W.: Health effects of fine particulate air pollution: Lines that connect, J. Air Waste Manage. Assoc., 56, 709-742, 2006.

Robinson, A. L., Donahue, N. M., Shrivastava, M. K., Weitkamp, E. A., Sage, A. M., Grieshop, A. P., Lane, T. E., Pierce, J. R., and Pandis, S. N.: Rethinking organic aerosols: Semivolatile emissions and photochemical aging, Science, 315, 1259-1262, 2007.
Seinfeld, J. H. and Pandis, S. N.: Atmospheric chemistry and physics: From air pollution to climate change, WileyInterscience, 1998.

Shi, J. P., Harrison, R. M., Evans, D. E., Alam, A., Barnes, C., and Carter, G.: A method for measuring particle numbers form vehicles driving on the road, Environ. Technol., 23, 1-14, 2002.

Shorter, J. H., Herndon, S., Zahniser, M. S., Nelson, D. D., Wormhoudt, J., Demerjian, K. L., and Kolb, C.: Real-time measurements of nitrogen oxide emissions from in-use new york city transit buses using a chase vehicle, Environ. Sci. Technol., 39, 7991-8000, 2005.

Singer, B. C., Harley, R. A., Littlejohn, D., Ho, J., and Vo, T.: Scaling of infrared remote sensor hydrocarbon measurements for motor vehicle emission inventory calculations, Environ. Sci. Technol., 32, 3241-3241, 1998.

Stephens, R. D., Mulawa, P. A., Giles, M. T., Kennedy, K. G., Groblicki, P. J., Cadle, S. H., and Knapp, K. T.: An experimental evaluation of remote sensing-based hydrocarbon measurements: A comparison to fid measurements, J. Air Waste Manage. Assoc., 46, 148-158, 1996.

Swedish Environmental Protection Agency, available online at: www.naturvardsverket.se (last access: 13 May 2013), 2013.

Ullman, T. L., Smith, L. R., Anthony, J. W., Slodowske, W. J., Trestrail, B., Cook, A. L., Bunn, W. B., Lapin, C. A., Wright, K. J., and Clark, C. R.: Copmparison of exhaust emissions, including toxic air contaminants, from school buses in compressed natural gas, low emitting diesel, and conventional diesel engine configurations, SAE Technical Paper Series, 2003-01-1381, 2003.

Valavanidis, A., Fiotakis, K., and Vlachogianni, T.: Airborne particulate matter and human health: Toxicological assessment and importance of size and composition of particles for oxidative damage and carcinogenic mechanisms, J. Environ. Sci Health Pt. C-Environ. Carcinog. Ecotoxicol. Rev., 26, 339-362, doi:10.1080/10590500802494538, 2008.

Vogt, R., Scheer, V., Casati, R., and Benter, T.: On-road measurement of particle emission in the exhaust plume of a diesel passenger car, Environ. Sci. Technol., 37, 4070-4076, 2003.

Wang, F., Ketzel, M., Ellermann, T., Wåhlin, P., Jensen, S. S., Fang, D., and Massling, A.: Particle number, particle mass and $\mathrm{NO}_{\mathrm{x}}$ emission factors at a highway and an urban street in Copenhagen, Atmos. Chem. Phys., 10, 2745-2764, doi:10.5194/acp-10-27452010, 2010.

Wang, H. K., Chen, C. H., Huang, C., and Fu, L. X.: Onroad vehicle emission inventory and its uncertainty analysis for shanghai, china, Sci. Total Environ., 398, 60-67, doi:10.1016/j.scitotenv.2008.01.038, 2008.

Wang, W. G., Clark, N. N., Lyons, D. W., Yang, R. M., Gautam, M., Bata, R. M., and Loth, J. L.: Emissions comparisons from alternative fuel buses and diesel buses with a chassis dynamometer testing facility, Environ. Sci. Technol., 31, 3132-3137, 1997. 